\title{
NILAI PENDIDIKAN KARAKTER RELIGIUS NOVEL RANTAU 1 MUARA KARYA AHMAD FUADI
}

\author{
Rahmat Gunawan \\ Universitas Sebelas Maret Surakarta Indonesia \\ Email: rahmatg02@gmail.com \\ Suyitno \\ Universitas Sebelas Maret Surakarta Indonesia \\ Email: yitsuyitno52@gmail.com \\ Slamet Supriyadi \\ Universitas Sebelas Maret Surakarta Indonesia \\ Email: pripus.lppmuns@yahoo.co.id
}

\begin{abstract}
This study aims to describe the values of religious character breeding in novel Rantau 1 Muara by Ahmad Fuadi. Novel Rantau 1 Muara is a novel that clearly tells of a value of struggle, persistence, obedience to God and a view of life that intends to achieve success with an incantation man saara ala darbi washala, who walks on His way will reach the goal. The method that is used in this research is qualitative descriptive method. The data resource in this study is novel Rantau 1 Muara by Ahmad Fuadi in 2013 with a total of 395 pages. The data in this research has the story units in dialogs, paragraphs, and tables that show the value of religious character breeding. The data collection techniques are done by using note taking techniques, and literature study. The steps are taken in analyzing the novel are by interpreting based on existing theories, then described according to the research objectives. The results of data analysis, there are 17 frequencies which are divided in, they are the religious existence of human relations to God such as worshiping, greeting, praying, giving thanks and asking forgiveness. The religious existences among human and human are asking for protection, worshiping parents, intimacy, and praying for others. Furthermore, the religious existence of human with nature is praising the beauty of nature.
\end{abstract}

Keywords: character, novel, religious 


\section{A. Pendahuluan}

Pendidikan karakter merupakan aset terpenting dalam kehidupan setiap manusia, baik secara individual maupun kelompok. Dalam setiap diri manusia pastilah berusaha untuk mendapatkan pendidikan yang layak dalam mencari ilmu pengetahuan. Pendidikan yang baik dan terarah akan memberikan manfaat yang bermanfaat juga di dalam kehidupan. Dalam novel Rantau 1 Muara, terdapat sebuah filosofi yang menyatakan hidup pada hakikatnya bahwa hidup adalah perantauan, di mana pada suatu saat akan kembali ke akarnya yaitu ke muara. Muara manusia adalah menjadi hamba sekaligus khalifah di muka bumi ini. Sebagai seorang hamba, tugas manusia adalah mengabdi. Sebagai khalifah, tugas manusia bermanfaat. Jadi, hidup adalah pengabdian dan kebermanfaatan. Dalam hal ini, diajarkan untuk memahami salah satu makna dalam novel ketiga dari Ahmad Fuadi yaitu Rantau 1 Muara ini dengan sebuah mantra "man sara ala al-darbi washala" (siapa yang berjalan dijalannya akan sampai di tujuan). Novel Rantau 1 Muara memberitahukan betapa pentingnya merantau di negeri orang, berpetualang dengan mewujudkan tekad dan cita-cita, selain dapat melihat dunia, juga dapat mengeluarkan dari zona nyaman dan lebih mandiri dengan bertahan mencari ilmu di negeri orang. Dengan merantau bisa mendapatkan apa yang diinginkan dalam mimpi yang harus diraih dalam cita-cita. Bukan hanya tujuan kebahagiaan dan keberhasilan dunia tapi juga tujuan hakiki seperti cita-cita yang diwujudkan dengan penuh usaha dan juga kegigihan. Jadi, membuat manusia sadar bahwa kehidupan itu tidak kekal, dan sesukses apapun di dunia akan kembali dalam kehidupan yang abadi, apakah akan sukses juga di akhirat kelak tergantung bekal di dunia.

Nilai pendidikan karakter yang terkandung dalam novel yang diuraikan menurut Kemendiknas dalam kajian penelitian ini berdasarkan 18 nilai pendidikan karakter meliputi: nilai religius, jujur, toleransi, disiplin, kerja keras, kreatif, mandiri, demokratif, rasa ingin tahu, semangat kebangsaan, cinta tanah air, menghargai prestasi, bersahabat, cinta damai, gemar membaca, peduli lingkungan, peduli sosial, dan tanggung jawab. ${ }^{1}$ Berlandaskan pada fungsi pendidikan menurut Undang-Undang RI Nomor 20 Tahun 2003 tentang Sistem Pendidikan Nasional, yaitu mengembangkan kemampuan dan membangun watak serta peradaban bangsa yang bermartabat dalam rangka mencerdaskan kehidupan bangsa dan untuk mengembangkan potensi peserta

\footnotetext{
${ }^{1}$ Agus Wibowo, Pendidikan Karakter (Yogyakarta: Pustaka Pelajar, 2012), 43-44
} 
didik agar menjadi manusia yang beriman dan bertakwa kepada Tuhan yang Maha Esa, berakhlak mulia, sehat, berilmu, cakap, kreatif, mandiri, dan menjadi warga negara yang demokratis serta bertanggung jawab.

Menurut Schaps dan Lewis, mengkonseptualisasikan pendidikan karakter sebagai instruksi yang mencari pengembangan warga peduli, berprinsip, dan bertanggung jawab. Pentingnya menumbuhkan pendidikan karakter di dalam diri agar ke depan menjadi lebih baik untuk mencapai suatu tujuan yang sempurna. ${ }^{2}$ Dari hal tersebut, unsur fundamental yang berakar pada nilai moral dari pendidikan itu sendiri terlupakan. Akibatnya pendidikan hanya menghasilkan manusia yang skolastik dan pandai secara intelektual namun kurang memiliki karakter utuh sebagai pribadi, yang seharusnya pendidikan karakter dapat menjadi kunci kesuksesan bagi pengembangan diri setiap individu. ${ }^{3}$

Dalam hal ini diperkuat dengan Permendikbud Nomor 23 Tahun 2015 Pasal 1 (2) tentang Penumbuhan Budi Pekerti, yaitu yang awalnya Penumbuhan Budi Pekerti dan selanjutnya disingkat menjadi PBP merupakan kegiatan pembiasaan sikap dan perilaku positif yang ada di sekolah yang dimulai sejak dari hari pertama sekolah, masa orientasi peserta didik baru untuk jenjang sekolah menengah pertama, sekolah menengah atas dan sekolah menengah kejuruan, sampai dengan kelulusan sekolah. Dalam pembelajaran yang berhubungan dengan kepribadian seseorang dan berorientasi pada pembentukan karakter peserta didik dapat diwujudkan melalui pengoptimalan pembelajaran sastra. Hal ini menjadi penting karena sastra dapat digunakan sebagai media yang strategis untuk meningkatkan mutu pendidikan karakter sekarang dan juga masa depan.

Seseorang dapat dikatakan berkarakter atau berwatak dalam kehidupannya jika ia telah berhasil menyerap nilai dan keyakinan yang dikehendaki masyarakat serta nantinya akan dapat digunakan sebagai kekuatan moral dalam hidupnya dengan hasil yang kebermanfaatan untuk diri sendiri maupun orang lain. Jika seseorang sejak lahir sudah diarahkan dan dibekali dengan nilai pendidikan karakter, maka kedepannya seseorang tersebut akan dapat menempatkan dimana posisi yang baik dan buruk. Hal itu

${ }^{2}$ E. Schaps and C. Lewis, "Perils on an essential journey: building school community," Phi Delta Kappan, 81, 3 (1999): 215

${ }^{3}$ JC. Sarros, et al., "Leadership and Character," Leadership and Organization Development Journal, Vol. 27, 8 (2006): 682 
tentu sangat menjadi hal yang positif untuk dapat diterapkan dalam kehidupan seharihari dan juga dalam dunia pendidikan.

Menurut Lickona, beberapa bentuk nilai pendidikan yang sebaiknya diajarkan yang ada di sekolah adalah kejujuran, keadilan, toleransi, kebijaksanaan, disiplin diri, tolong menolong, peduli sesama, kerja sama, keberanian, dan sikap demokratis. Nilai pendidikan karakter tersebut berkaitan dengan pengetahuan moral (moral knowing), perasaan moral (moral felling), dan perilaku moral (moral behavior). ${ }^{4}$ Berdasarkan ketiga komponen ini dapat dinyatakan bahwa karakter yang baik didukung oleh pengetahuan tentang kebaikan, keinginan untuk berbuat baik, dan melakukan perbuatan kebaikan. Ada beberapa komponen karakter baik, di antaranya: 1) pengetahuan moral meliputi: kesadaran moral, pengetahuan nilai moral, pengetahuan perspektif, pemikiran moral, pengambilan keputusan, pengetahuan pribadi; (2) perasaan moral meliputi: hati nurani, harga diri, empati, mencintai hal yang baik, kendali diri, kerendahan hati. Dari dua paparan tersebut tercipta sebuah; dan (3) tindakan moral meliputi: kompetensi, keinginan, dan kebiasaan.

Pendidikan karakter merupakan salah satu dari beberapa solusi untuk mengatasi masalah degradasi moral yang terjadi pada bangsa ini. Pengembangan pendidikan budaya dan karakter yang terintegrasi dalam proses pembelajaran berupa pengenalan nilai melalui fasilitas yang didapat menyadari pentingnya nilai dalam kehidupan, dan nilai internalisasi ke dalam perilaku siswa setiap hari melalui proses belajar baik yang terjadi di dalam dan di luar kelas di semua mata pelajaran. Pendidikan karakter sama tuanya dengan pendidikan itu sendiri. Manfaatnya turun sepanjang sejarah, pendidikan telah memiliki dua tujuan besar yaitu membantu orang menjadi cerdas dan membantu mereka menjadi baik. ${ }^{5}$

Karakter berhubungan dengan kekuatan karakter, yang berkonotasi 'positif' nilainya, tidak netral. Dengan demikian, seseorang dengan karakter adalah orang yang memiliki kualitas moral positif tertentu. 'Kekuatan karakter' berhubungan langsung dengan kebajikan. ${ }^{6}$ Sedangkan kekuatan karakter dilihat sebagai unsur psikologis yang

${ }^{4}$ T. Lickona, Educating for Character: Mendidik untuk Membentuk Karakter, Terj. Juma Wadu Wamaungu (Jakarta: Bumi Aksara, 2016), 75

${ }^{5}$ T. Lickona, "The return of character education," Educational Leadership 51, 3 (1993): 6

${ }^{6}$ Kokom Komalasari \& Didin Saripudin, "The Influence of Living Values Education-Based Civic Education Textbook on Student's Character Formation," International Journal of Instruction, Vol. 11, No.1 (2018): 395 
menumbuhkan kebajikan. Salah satu kriteria utama karakter kekuatan adalah bahwa karakter tersebut berkontribusi besar untuk sepenuhnya mengaktualisasikan potensi seseorang dan cita-cita dalam membangun kehidupan yang baik, yang bermanfaat bagi diri sendiri dan orang lain. ${ }^{7}$

Jika melihat pada karakter bangsa Indonesia didasarkan pada Pancasila sebagai fondasi bangsa dan visi hidup bangsa Indonesia. Karakter ini sesuai dengan nilai hidup, yaitu berbagai kebiasaan yang secara universal mendasari baik dan harmonis hubungan antar masyarakat. Nilai pribadi dan sosial mencakup perdamaian, penghargaan, cinta, tanggung jawab, kebahagiaan, kerja sama, kejujuran, kerendahan hati, toleransi, kerendahan hati, kebebasan dan persatuan. ${ }^{8}$ Karakter yang baik terdiri dari pengertian, kepedulian, dan bertindak berdasarkan inti nilai etika. Menurut Lickona, Kemitraan Pendidikan Karakter (Character Education Partnership - CEP) telah mengidentifikasi 11 prinsip pendekatan komprehensif terhadap pendidikan karakter, di antaranya promosikan nilai etika inti sebagai dasar karakter yang baik. Tentukan karakter secara komprehensif untuk memasukkan pemikiran, perasaan, dan perilaku. Gunakan pendekatan yang komprehensif, disengaja, proaktif, dan efektif. Buat komunitas sekolah yang peduli. Berikan siswa kesempatan untuk terlibat dalam tindakan moral. Berikan kurikulum yang bermakna dan menantang yang membantu semua siswa untuk sukses. Berikan motivasi siswa untuk belajar dan menjadi orang baik. Libatkan staf sekolah sebagai profesional dalam komunitas pembelajaran dan moral. Dukung kepemimpinan moral bersama dan dukungan jangka panjang untuk pendidikan karakter. Melibatkan keluarga dan anggota masyarakat sebagai mitra dalam pendidikan karakter. Evaluasi karakter sekolah, stafnya, dan siswanya untuk menginformasikan upaya pendidikan karakter. ${ }^{9}$

Kemendiknas BPPPK berpendapat bahwa pendidikan budaya dan karakter bangsa dimaknai sebagai pendidikan yang mengembangkan nilai-nilai budaya dan karakter bangsa pada diri peserta didik sehingga mereka memiliki nilai dan karakter sebagai karakter dirinya, menerapkan nilai-nilai tersebut dalam kehidupan dirinya,

${ }^{7}$ C. Peterson, \& M.E.P. Seligman, Character strengths and virtues a handbook and classification (Washington D. C.: APA Press and Oxford University Press, 2004), 241

${ }^{8}$ D. Tillman, Living values: Avtivities for children ages 8-14 (Jakarta: PT Gramedia Widiasarana Indonesia, 2004), 67

${ }^{9}$ T. Lickona, E. Schaps, \& C. Lewis, CEP's Eleven Principles of Effective Character Education (Washington DC: Character Education Partnership, 2003), 321. 
sebagai anggota masyarakat, dan warga negara yang religius, nasionalis, produktif dan kreatif. ${ }^{10}$ Menurut Lickona, pendidikan karakter yang efektif membutuhkan pendekatan yang bersifat proaktif, komprehensif, dan harus intensif. ${ }^{11}$

Menurut Sunarti berpendapat bahwa karakter merupakan istilah yang menunjuk kepada aplikasi nilai-nilai kebaikan dalam bentuk tingkah laku. Walaupun istilah karakter dapat menunjuk kepada karakter baik atau karakter buruk, namun dalam aplikasinya orang dikatakan berkarakter jika mengaplikasikan nilai-nilai kebaikan dalam perilakunya. ${ }^{12}$ Jika melihat pendidikan karakter merupakan usaha untuk dikembangkan kebajikan yang memungkinkan kita memimpin pemenuhan hidup dan membangun dunia yang lebih baik. ${ }^{13}$

Tanpa ada karakter dasar, pendidikan karakter tidak akan memiliki tujuan yang pasti. Perlu sebuah ketetapan karakter apa saja yang dibutuhkan siswa untuk mengembangkan kepribadiannya. Sementara pendidikan karakter dipandang sebagai bagian dari pendidikan kewarganegaraan dalam kurikulum hal itu dikemukakan menurut Revell. ${ }^{14}$ menurut Healea, oleh karena itu membentuk karakter anak harus dimulai sedini mungkin bahkan sejak anak itu dilahirkan. Pendidikan bertujuan untuk memberi para siswa kompas moral internal untuk mengenali yang baik, menginginkan yang baik dan melakukan apa yang baik. ${ }^{15}$

\section{B. Metode}

Adapun objek dalam penelitian ini adalah karya sastra berupa novel yang berjudul Rantau 1 Muara karya Ahmad Fuadi terbitan pertama tahun 2013. Novel ini merupakan sebuah novel yang di dalamnya mengandung nilai-nilai pendidikan karakter religius. Novel ini mengajarkan kita tentang sebuah semangat perjuangan, serta pandangan hidup dalam sebuah harapan. Novel ini terdiri dari 395 halaman yang diterbitkan oleh penerbit Gramedia Pustaka Utama. Dari tujuan dan masalah yang dituturkan, pada penelitian ini menggunakan metode deskriptif kualitatif. Metode ini digunakan untuk mendeskripsikan data tertulis dalam novel Rantau 1 Muara karya

\footnotetext{
${ }^{10}$ Kemendiknas, Pengembangan Pendidikan Budaya dan Karakter Bangsa (Jakarta: t.p., 2010), 4

${ }^{11}$ T. Lickona, Educating for Character (New York: Bantam Books, 1991), 226

${ }^{12}$ Euis Sunarti, Menggali Kekuatan Cerita (Jakarta: PT Elek Media Komputindo, 2005), 65

${ }^{13}$ T. Lickona, Educating..., 228

${ }^{14}$ L. Revell \& J. Arthur, "Character education in schools and the education of teachers," Journal of Moral Education, 36, 1 (2007): 79

${ }^{15} \mathrm{C}$. Healea, "Character education with resident assistant: A model fordevelopment character on college campus," The Journal of Education, 186, 1 (2006): 65-77.
} 
Ahmad Fuadi yang di dalamnya terdapat nilai pendidikan karakter religius yang terjalin dalam tokoh Alif dalam masa perantauannya sebagai tempat berkarya, pencarian belahan jiwa dan juga pencarian di mana hidup akan bermuara.

Data yang terdapat dalam penelitian ini mencakup tentang satuan cerita dalam dialog, paragraf, dan tabel yang menunjukan nilai pendidikan karakter religius dalam novel Rantau 1 Muara. Teknik pengumpulan data dilakukan dengan teknik simak, catat, dan pustaka. Teknik ini dilakukan dengan membaca novel secara berulang-ulang agar mendapatkan data yang akurat. ${ }^{16}$ Dalam mengolah data dalam penelitian, teknik analisis data dengan menginterpretasikan data, membaca keseluruhan data, menganalisis lebih detail, menerapkan proses koding untuk dideskripsikan, menyajikan kembali dalam narasi, dan menginterpretasikan atau memaknai data. ${ }^{17}$

\section{Hasil Penelitian dan Pembahasan}

Novel Rantau 1 Muara adalah novel yang mengajarkan tentang sebuah perjuangan dan semangat berjuang, nilai moral, cinta kasih, kekerabatan, tanggung jawab, pandangan hidup, serta sebuah harapan. Novel Rantau 1 Muara ini dideskripsikan dengan mengambil cerita dari sebuah pengalaman pribadi penulisnya dalam pencarian tempat berkarya, pencarian belahan jiwa dan juga pencarian dimana hidup akan bermuara. Dengan latar cerita di kota Jakarta, Washington DC yang merupakan kota impian penulis, dan kembali bermuara pada tanah air Indonesia di (Jakarta). Pada saat itu sosok Alif yang merasa berdiri di pucuk dunia, dia telah mengelilingi sebagian dunia, tulisan-tulisan yang dibuatnya sudah tersebar di berbagai media, dan beliau menjadi lulusan dengan nilai terbaik. Dengan penuh harapan nantinya akan ada banyak perusahaan yang merekrutnya, namun pada saat itu dirinya lulus pada masa yang tidak tepat yaitu pada saat reformasi yang banyak perusahaan menolak surat lamarannya. Alif mulai bimbang, namun dengan secercah harapan ketika dirinya menjadi seorang wartawan di majalah terkenal saat itu, dia jatuh cinta kepada gadis yang dahulu pernah dicurigainya. Di kota Jakarta terciptalah sebuah harapan baru, Alif mendapatkan beasiswa ke Washington DC, dan saat Alif tinggal di Amerika, dirinya

\footnotetext{
${ }^{16}$ Sugiyono, Metode Penelitian Pendidikan Pendekatan Kuantitatif, Kualitatif, dan $R \& D$ (Bandung: Alfabeta, 2014), 224

${ }^{17}$ J. W. Creswell, Research Design: Pendekatan Kualitatif, Kuantitatif, dan Mixed (Yogyakarta: PT Pustaka Pelajar, 2010), 245
} 
memiliki teman dan pekerjaan yang baik, dengan berkehidupan yang mencukupi dengan tujuan untuk membantu adik-adiknya dan juga Amak tercapai juga. Sampai dirinya menyaksikan sebuah peristiwa pada tanggal 11 september 2001 di gedung World Trade Center di kota New York, dan orang terdekat Alif menghilang dari peristiwa tersebut.

Oleh karena itu, dirinya harus memikirkan misi hidupnya kembali akan kemanakah tujuannya. Dengan memiliki mantera sewaktu mondok dahulu "man sara ala al-darbi washala" (siapa yang berjalan di jalannya akan sampai tujuan) yakni menuju kepada Sang Khaliq. Berpetualang dengan mewujudkan tekad dan cita-cita, selain dapat melihat dunia juga dapat berkarya, mengeluarkan dari zona nyaman dan lebih mandiri dengan bertahan mencari ilmu di negeri orang. Dengan merantau, bisa mendapatkan apa yang diinginkan dalam mimpi yang harus diraih dalam cita-cita. Bukan hanya tujuan kebahagiaan dan keberhasilan dunia tetapi juga tujuan hakiki seperti cita-cita yang diwujudkan dengan penuh usaha dan juga kegigihan. Jadi, membuat sadar bahwa kehidupan itu tidak kekal, dan sesukses apapun di dunia akan kembali dalam kehidupan yang abadi, apakah akan sukses juga di akhirat kelak tergantung bekal di dunia. Berawal dari sebuah perjalanan pencarian misi hidup yang pada hakikatnya adalah sebuah perantauan. Jadi novel Rantau 1 Muara menceritakan tentang sebuah konsistensi dalam menuju tujuan, pencarian belahan jiwa, menemukan tempat bermuara, muara dari segala muara.

Deskripsi mengenai nilai pendidikan karakter religius pada novel Rantau 1 Muara, di mana penelitian tiap butir permasalahan yang termasuk dalam nilai religius yang ditampilkan pada tabel 1.

Berikut ini dipaparkan pembahasan tentang nilai-nilai pendidikan karakter pada novel Rantau 1 Muara karya Ahmad Fuadi, yang di dalamnya terdapat nilai pendidikan karakter religius. Religius merupakan suatu sikap serta perilaku yang patuh untuk menjalankan ajaran dalam agama serta dapat toleran kepada agama lain dalam menjalankan ibadah. Hidup bersama-sama saling menghargai, rukun dengan agama lainnya. Dalam karakter religius harus menjadi bekal oleh setiap orang dalam menghadapi setiap perubahan-perubahan zaman, agar nantinya dapat berprilaku baik serta terciptanya moral yang baik. Nilai-nilai religius yang terdapat dalam novel Rantau 1 Muara adalah: 


\section{Wujud Nilai Religius Hubungan Manusia dengan Tuhan}

\section{a. Beribadah}

Nilai religius yang termasuk ke dalam kategori ibadah dapat dibuktikan pada kutipan berikut:

"Ramadan dan Idul Fitri datang ke DC dengan kemeriahan tersendiri. Kami berdua berusaha sering hadir di tarawih bersama di KBRI yang diimami Ustad Fariz, yang dikelola oleh Ikatan Muslim Indonesia. Kalau tidak sempat berjalan ke KBRI yang cukup jauh, kami salat di musala kampus. Kadang kala, kami mencoba pula salat di Islamic Center Washington DC yang gagah di Embassy Row, Massachusetts Avenue."18

Pada kutipan di atas termasuk ke dalam hubungan ibadah manusia dan Tuhannya, yaitu dengan ikut memeriahkan serta meramaikan kegiatan pada waktu bulan Ramadan. Kami melakukan ibadah shalat dan tarawih bersama-sama dengan rekan yang lain, melakukan ibadah merupakan hal yang wajib untuk umat beragama, sebagai tanda patuh dan bakti manusia kepada Tuhan. Kutipan lainnya yang termasuk ke dalam beribadah, hal tersebut dapat dibuktikan pada kutipan berikut.

"Akhirnya kami sepakat untuk meminta petunjuk-Nya. 'Cinta, kita salat istikharah yuk. Dia selalu tahu apa yang paling baik buat kita,' ajakku."19

Pada kutipan di atas termasuk dalam hubungan ibadah manusia kepada Tuhannya. Saat pikiran dipenuhi kepayang dan juga kebingungan, maka pilihan yang tepat adalah meminta petunjuk dari Allah supaya diberikan kemudahan dan ditunjukan pilihan yang baik saat itu. Akhirnya Alif dan Dinara sepakat untuk melaksanakan salat istikharah berdua. Selalu percaya perbuatan yang baik dan ikhlas akan dibalas juga dengan hal yang baik.

\section{b. Mengucap Salam}

Nilai religius yang termasuk ke dalam mengucap salam dapat dibuktikan pada kutipan berikut:

"Assalamualaikum, ketemu lagi kita, sapaku iseng ke sisi kamar."20

Pada kutipan di atas tokoh Alif menunjukan bahwa termasuk nilai religius dengan mengucapkan salam saat masuk kamar yang sudah lama ditinggalkannya.

\footnotetext{
${ }^{18}$ Ahmad Fuadi, Rantau 1 Muara (Jakarta: Gramedia Pustaka Utama Gramedia Widiasarana Indonesia, 2013), 361

${ }^{19}$ Ibid., 385

${ }^{20}$ Ibid., 1
} 
Mengucapkan salam termasuk sebuah nilai religius yang harus diajarkan dalam agama Islam.

\section{c. Berdoa}

Nilai religius yang termasuk ke dalam kategori berdoa dapat dibuktikan pada kutipan berikut:

"Dengan memejamkan mata dan menyebut basmalah, aku lepas surat-surat

lamaran itu terbang ke lusinan organisasi internasional dan korporasi." ${ }^{21}$

Pada kutipan di atas, terdapat kata bismilah yang termasuk dalam nilai religius yang biasanya diucapkan pada saat seseorang akan melakukan sesuatu yang berharap sebuah pengharapan yang berkah. Kutipan lainnya yang termasuk ke dalam berdoa dapat dibuktikan sebagai berikut:

"Dengan pelupuk mata yang berat, aku bubungkan doaku terakhir sebelum tidur.

Ya Tuhan, mudahkanlah jalanku menuntut ilmu ke negeri orang. Lalu aku telungkupkan buku TOEFL ke mukaku, siapa siapa tahu malam ini isi buku ini mencair dan mengalir pindah ke otakku."22

Pada kutipan di atas termasuk nilai religius, yang mana doa adalah permintaan seseorang hamba kepada penciptanya (Allah) agar semua urusan yang telah dilakukannya mendapat kemudahan dan juga bisa sukses nantinya.

\section{d. Bersyukur}

Ungkapan yang termasuk ke dalam kategori bersyukur dapat dibuktikan pada kutipan berikut:

"Alhamdulillah, do'a dan usaha itu memang selalu didengar-Nya."23

Pada kutipan ini yang menunjukkan nilai religius adalah ucapan Alhamdulillah, yang merupakan suatu ungkapan seseorang pada saat telah melakukan sesuatu atau lebih tepatnya bersyukur kepada Tuhan yang telah dikaruniai nikmatnya. Kutipan lainnya yang termasuk ke dalam bersyukur adalah sebagai berikut:

"Ingin aku melompat setinggi-tingginya dan berteriak lega sekeras-kerasnya.

Impian besar itu tercapai jua akhirnya. Alhamdulillah, ya Tuhan janji-Mu

\footnotetext{
${ }^{21}$ Ibid., 18

${ }^{22}$ Ibid., 156

${ }^{23}$ Ibid., 31
} 
memang tidak meleset, apa yang di-perjuangkan dengan sepenuh hati dan raga, lambat laun akan sampai". ${ }^{24}$

Bersyukur atau berterima kasih ke-pada Tuhan Yang Maha Esa adalah sikap yang menghargai nikmat yang telah diberikan oleh Allah SWT kepada umatnya. Syukur berarti memfungsikan seluruh kenikmatan Allah pada tujuan yang sebenarnya. Bersyukur merupakan rasa nikmat atas segala karunia Allah SWT dengan mengucapkan Alhamdulillah sebagai ungkapan rasa syukur dan terima kasih kepada-Nya. Pada kutipan di atas, ucapan syukur kembali diucapkan oleh tokoh dengan mengucapkan Alhamdulillah sebagai ucapan terima kasih kepada Allah karena ia merasakan kebesaran Allah yang telah melihat kesungguhannya dan kerja kerasnya dalam meraih impian di sertai dengan pendekatan kepada Allah dengan menjalankan perintah-Nya dan menjauhi larangan-Nya.

\section{e. Mohon Ampun}

Dalam novel Rantau Satu Muara (R1M), tokoh Alif tetap berusaha untuk melakukan shalat tengah malam atau shalat tahajud di samping shalat wajib, dan ia merasakan kebesaran Tuhan dalam shalatnya. Hal ini terlihat dalam kutipan berikut:

"Malam-malam aku bangun dan bersimpuh di sajadah minta kemudahan dalam hidup dan karierku." 25

Pada kutipan di atas, menandakan Alif melaksanakan perintah Allah dengan mengerjakan shalat dan mengamalkan perbuatan baik yang bernilai ibadah agar mendapat ridho dari Allah Swt yang kemudian memberikan ketenangan batin dalam dirinya. Shalat adalah bentuk peribadatan kepada Tuhan Yang Maha Esa. Melalui shalat kita akan membangun kedekatan dengan sang pencipta. Shalat merupakan bentuk ibadah yang paling utama dan merupakan esensi dari peng-abdian manusia kepada penciptanya. Dengan mengerjakan shalat secara tertib dan tepat waktu menandakan kepatuhan sekaligus kebaktian seorang hamba terhadap Tuhannya.

\section{Wujud Nilai Religius Hubungan Manusia dengan Manusia}

\section{a. Meminta Perlindungan}

Ungkapan yang termasuk ke dalam meminta perlindungan dapat dibuktikan pada kutipan berikut:

\footnotetext{
${ }^{24}$ Ibid., 186

${ }^{25}$ Ibid., 71
} 
“Saya orangya, kataku dengan suara dimantap-mantapkan. Hatiku berdo'a untuk berlindung dari orang yang berniat jahat dan terkutuk." 26

Pada kutipan di atas menunjukan bahwa termasuk dalam nilai religius yang ditunjukkan pada kutipan "Hatiku berdo'a untuk berlindung dari orang yang berniat menjahati aku jahat dan terkutuk," yang memperlihatkan bahwa tindakan berdoa, berserah diri dan juga meminta perlindungan kepada Tuhan agar dijauhkan dari orang yang ingin berniat jahat dan mencelakai dirinya.

\section{b. Berbakti kepada orang tua}

Berikut ini adalah contoh kutipan yang termasuk ke dalam berbakti pada orang tua, hal tersebut dapat dibuktikan pada kutipan berikut.

"Aku duduk bersimpuh di depan Amak dan tidak berani beringsur sampai mendengar jawabannya. Setelah beberapa saat diam, Amak mengulang nasihatnya lagi, kemanapun dan apa-pun yang waang lakukan, selalu perbaharui niat, bahwa hidup singkat kita ini hanya karena Allah dan untuk membawa manfaat. Jangan berorientasi materi. Kalau memang sekolah jauh itu membawa manfaat dan waang niatkan sebagai ibadah, pailah, pergilah.,"27

Di dalam kutipan di atas terlihat bahwa nilai pendidikan religius dengan indikator ikhlas adalah nasihat dari Amak yang menyatakan bahwa hidup singkat ini hanya karena Allah. Oleh karena itu, pergunakanlah dengan jalan yang diridhai-Nya dan mengamalkan segala perbuatan baik yang bernilai ibadah. Ikhlas berkaitan dengan tindakan dan perilaku seseorang yang dilakukan tanpa pamrih, hanya semata-mata mengharapkan keridhaan Allah.

\section{c. Keakraban}

Ungkapan yang termasuk ke dalam keakraban terdapat pada kutipan berikut:

"Aku bersyukur sekali, kami berdua ternyata tidak hanya bisa menjadi pasangan hidup, tapi juga menjadi mitra kerja yang andal. Kami bagai dua elemen kimia yang jika digabungkan menjadi elemen baru yang kuat. Ketika seorang diri, kami hanya satu pribadi biasa, ketika bersatu, kami menjadi tim yang luar biasa. Kami saling melengkapi. Kami adalah satu."28

Kutipan di atas menunjukan bahwa menunjukan nilai religius yang melakukan sikap bersyukur karena sudah dipasangkan untuk berdua yang menjadikan sempurna. Ditunjukkan pada kutipan "Kami bagai dua elemen kimia yang jika digabungkan

\footnotetext{
${ }^{26}$ Ibid., 36

${ }^{27}$ Ibid., 174

${ }^{28}$ Ibid., 313
} 
menjadi elemen baru yang kuat. Ketika seorang diri, kami hanya satu pribadi biasa, ketika bersatu, kami menjadi tim yang luar biasa, kami saling melengkapi. Kami adalah satu.” Kutipan lainnya yang termasuk ke dalam keakraban adalah sebagai berikut:

"Menjelang pengujung Ramadan, aku diminta Ustad Fariz ikut menjadi juri lomba azan dan mengaji, serta pernah pula jadi imam salat Tarawih. Dinara dapat tugas menjadi pembaca acara Nuzulul Qur`an dan bersama ibu-ibu punya kesibukan sendiri mengatur penyaluran infak, menyiapkan buka bersama, dan lomba mengaji para ibu." 29

Pada kutipan di atas termasuk ke dalam hubungan keakraban manusia dengan manusia. Alif menjadi bagian memeriahkan bulan Ramadan sebagai juri lomba azan dan juga menjadi imam salat tarawih merupakan kebanggaan tersendiri. Dinara pun tidak mau kalah dengan mencari kesibukan sebagai pembaca acara di sebuah acara di penghujung Ramadan yaitu acara Nuzulul Qur`an. Selain mengamalkan hal-hal yang baik kepada masyarakat tentunya Alif dan Dinara merupakan pasangan yang kompak dan akrab menciptakan hal-hal terbaru untuk dibagikan kepada orang lain.

\section{d. Mendoakan orang lain}

Salah satu nilai religius yang termaktub dalam novel Rantau 1 Muara adalah mendoakan orang lain, sebagaimana terdapat pada kutipan berikut:

"Selesai mengatupkan kedua tanganku di wajah sebagai penutup doa, aku ambil al-Qur`an kecilku di rak mushala. Hari Kamis malam Jumat biasanya jadwalku membaca yasin. Aku niatkan mengirimi kebaikan bacaan mulia ini untuk almarhum Ayah dan keluargaku yang telah mendahului kami." 30

Pada kutipan ini kebiasaan berdoa ditunjukkan oleh Alif setelah melakukan shalat dan membaca al-Qur`an sehabis shalat kemudian mengirim doa kepada almarhum Ayah dan keluarga yang telah dahulu berpulang ke rahmatullah. Berdoa adalah memohon atau meminta sesuatu yang bersifat baik kepada Allah SWT. agar diberikan kemudahan atau kelancaran dalam hidup. Berdoa memberikan gambaran bahwa seseorang sangat butuh bantuan dan pertolongan dari Sang Pencipta. Yang termasuk ke dalam mendoakan orang lain terdapat juga pada kutipan berikut:

"Aku bersimpuh lama-lama di sajadah. Doa utamaku tetap berharap akan keselamatan Mas Garuda. Tapi mungkin aku harus mulai berdamai dengan keadaan dan mendoakan akhir terbaik buatnya, hidup maupun mati. Bukan-kah semua yang hidup pasti berakhir dengan kematian. Hanya soal waktu saja.

${ }^{29}$ Ibid., 362

${ }^{30}$ Ibid., 149 
Kalaupun dia telah mati tidak dengan sia-sia. Mas Garuda yang se-lalu ringan tangan membantu orang lain. Semoga dia mendapatkan husnul khatimah, akhir yang baik." 31

Pada kutipan di atas, Alif mendoakan Mas Garuda dan tetap berharap atas keselamatannya, dan Alif telah bisa mengikhlaskannya dengan bertawakal atau berserah diri sepenuhnya kepada Allah dalam menghadapi kesedihannya atas kehilangan Mas Garuda. Sesudah beragam usaha yang dilakukannya dengan pencarian, dengan selalu berdoa, maka Alif menggantungkan semuanya kepada Allah agar ia bisa merelakan dengan perasaan yang ikhlas. Bertawakal merupakan berserah diri sepenuhnya kepada Allah dalam menghadapi, menanti atau menunggu hasil pekerjaan. Bertawakal juga penyerahan se-suatu kepada Allah atau mengantungkan urusan diri pada Allah. Tawakal adalah satu bentuk hubungan makhluk dengan Sang Khalik tawakal juga diartikan sebagai pemasrahan diri secara total. Sesudah beragam usaha dilakukan, dan berbagai doa dipanjatkan, maka yang terakhir adalah tawakal. Sikap tawakal menghindarkan seseorang dari sifat cemas, stress, dan sebagainya. Kutipan lainnya yang termasuk ke dalam mendoakan orang lain adalah sebagai berikut:

“Ambo akan pulang ke kampung 2 x 11 Enang Lingkung, dekat-dekat dengan Ibu. Kebelutan pula ambo sudah diminta oleh rektor Unand untuk jadi dosen. Begitu pula Uni Reza akan kembali ke almamaternya di IKIP. Tapi impian kami berdua itu ingin membuat sekolah SMA berasrama yang bagus. Terbagus di Sumatera Barat. Insya Allah. Amin, amin, kata kami mendoakan." 32

Pada kutipan di atas termasuk ke dalam hubungan mendoakan orang lain dari manusia dengan manusia. Suatu saat nanti Alif akan pulang dan mengabdi di salah satu perguruan tinggi yang ada di Sumatera Barat untuk menjadi dosen. Serta mempunyai keinginan yang sangat berkah sekali yaitu membuat sekolah menengah pertama paling bagus di Sumatera Barat. Hal hal tersebut seperti mengabdi dan juga keinginan yang sangat besar merupakan upaya yang semestinya diwujudkan dengan harapan serta kerja keras. Sebagai manusia juga wajib mendoakan hal-hal yang baik kepada orang lain agar menjadi suatu keberkahan yang berujung indah.

\footnotetext{
${ }^{31}$ Ibid., 356-357

${ }^{32}$ Ibid., 365
} 


\section{Wujud Nilai Religius Hubungan Manusia dengan Alam Sekitar}

\section{a. Memuji keindahan alam}

Nilai religius yang menggambarkan hubungan manusia dengan alam sekitar adalah memuji keindahan alam, hal tersebut dapat dibuktikan pada kutipan berikut:

“Masya Allah, indahnya!" teriak Dinara. Aku mengangguk mengiyakan sambil mataku mengeker dan sibuk menjepret foto sana-sini." 33

Pada kutipan di atas menunjukan adanya nilai religius, hal itu dibuktikan dengan kutipan "Masya Allah, indahnya!". Hal tersebut menandakan keberkahan dengan artian bersyukur atas keindahan dan mengagumi apa yang telah Allah ciptakan di dunia ini, sehingga hal tersebut harus disyukuri dengan senang hati.

Dari ketiga wujud nilai karakter religius tersebut yang frekuensinya sebanyak 17 ungkapan, satu dengan yang lainnya saling berkaitan, bahwa setiap manusia harus memiliki nilai-nilai pendidikan karakter religius yang dapat dijadikan pedoman dalam hidupnya agar rasa yang ada di dalam diri bisa seimbang serta diajarkan dalam kehidupan sehari-hari. Dari hasil analisis tersebut menunjukan bahwa pada diri manusia memiliki nilai-nilai pendidikan karakter religius yang dapat ditemui dalam kehidupan sehari-hari.

\section{Kesimpulan}

Nilai pendidikan karakter religius pada novel Rantau 1 Muara karya Ahmad Fuadi, dapat diketahui bahwa nilai karakter religius tersebut terdapat dalam keseluruhan isi novel. Pada nilai-nilai pendidikan karakter yang terdapat pada novel Rantau 1 Muara ini menggambarkan bagaimana manusia harus bersikap dan bertindak dalam menjalani kehidupan sesuai nilai yang kita dapatkan. Dari karakter religius yang terdapat pada novel Rantau 1 Muara karya Ahmad Fuadi ini terbagi meliputi wujud religius hubungan manusia dengan Tuhan, di antaranya beribadah, mengucap salam, berdoa, bersyukur dan mohon ampun. Wujud nilai religius hubungan manusia dengan manusia di antaranya meminta perlindungan, berbakti kepada orang tua, keakraban, dan mendiakan orang lain. Selanjutnya wujud religius hubungan manusia dengan alam yaitu memuji keindahan alam.

\footnotetext{
${ }^{33}$ Ibid., 302
} 


\section{E. Daftar Pustaka}

Creswell, J. W. Research Design: Pendekatan Kualitatif, Kuantitatif, dan Mixed. Yogyakarta: PT Pustaka Pelajar, 2010

Fuadi, Ahmad. Rantau 1 Muara. Jakarta: Gramedia Pustaka Utama Gramedia Widiasarana Indonesia, 2013.

Healea, C. "Character education with resident assistant: A model fordevelopment character on college campus.” The Journal of Education, 186, 1 (2006): 65-77.

Kemendiknas, Pengembangan Pendidikan Budaya dan Karakter Bangsa. Jakarta: t.p., 2010.

Komalasari, Kokom \& Saripudin, Didin. "The Influence of Living Values EducationBased Civic Education Textbook on Student's Character Formation," International Journal of Instruction, Vol. 11, No.1 (2018): 395-410.

Lickona, T. "The return of character education." Educational Leadership 51, 3 (1993): 6-11.

Lickona, T. Educating for Character. New York: Bantam Books, 1991.

Lickona, T. Educating for Character: Mendidik untuk Membentuk Karakter. Terj. Juma Wadu Wamaungu. Jakarta: Bumi Aksara, 2016.

Lickona, T. Schaps, E. \& Lewis, C. CEP's Eleven Principles of Effective Character Education. Washington DC: Character Education Partnership, 2003.

Peterson, C. \& Seligman, M.E.P. Character strengths and virtues a handbook and classification. Washington D. C.: APA Press and Oxford University Press, 2004.

Revell, L. \& Arthur, J. "Character education in schools and the education of teachers." Journal of Moral Education, 36, 1 (2007): 79-92.

Sarros, JC., et al. "Leadership and Character." Leadership and Organization Development Journal, Vol. 27, 8 (2006): 682-699.

Schaps, E. and Lewis, C. "Perils on an essential journey: building school community." Phi Delta Kappan, 81, 3 (1999): 215-218.

Sugiyono. Metode Penelitian Pendidikan Pendekatan Kuantitatif, Kualitatif, dan R\&D. Bandung: Alfabeta, 2014

Sunarti, Euis. Menggali Kekuatan Cerita. Jakarta: PT Elek Media Komputindo, 2005.

Tillman, D. Living values: Avtivities for children ages 8-14. Jakarta: PT Gramedia Widiasarana Indonesia, 2004

Wibowo, Agus. Pendidikan Karakter. Yogyakarta: Pustaka Pelajar, 2012 


\section{LAMPIRAN-LAMPIRAN}

Tabel 1. Nilai Pendidikan Karakter Religius yang Terdapat dalam Novel Rantau 1 Muara Karya Ahmad Fuadi

\begin{tabular}{llcc}
\hline No & Nilai Pendidikan Karakter Religius & Halaman & Frekuensi \\
\hline 1. & $\begin{array}{l}\text { Wujud nilai religius hubungan } \\
\text { manusia dengan Tuhan }\end{array}$ & & \\
\hline & a. Beribadah & 361,385 & 2 \\
\hline b. Mengucap salam & 1 & 1 \\
\hline c. Berdoa & 18,156 & 2 \\
\hline d. Bersyukur & 31,186 & 2 \\
\hline e. Mohon ampun & 71 & 1 \\
\hline 2. & $\begin{array}{l}\text { Wujud nilai religius hubungan } \\
\text { manusia dengan manusia }\end{array}$ & 1 \\
\hline & a. Meminta perlindungan & 1 \\
\hline b. Berbakti kepada orang tua & 36 & 2 \\
\hline c. Keakraban & 174 & 4 \\
\hline d. Mendoakan orang lain & $149,356-357,365$ & 1 \\
\hline Wujud nilai religius hubungan \\
manusia dengan alam sekitar
\end{tabular}

